\title{
Penerapan Metode Certainty Factor Untuk Mediagnosa Penyakit Depresi Pada Manusia Menggunakan PHP Dan Mysql
}

\author{
Hidayatullah ${ }^{1}$, Andri Nata ${ }^{2}$, Adi Prijuna Lubis ${ }^{3}$ \\ STMIK ROYAL KISARAN \\ Jl. Prof. H.M. Yamin No. 173 Telp. 0623-41079, Fax. 0623-42366 Kisaran \\ dayatscorpio2@gmail.com¹, andrinata0202@gmail.com², pri7n4@gmail.com³
}

\begin{abstract}
The purpose were design and develop software engineering web based expert system to diagnose depression on human to get solution and information easily and rapidly. This research used Certainty Factor of analyzed method base of user answer for question in this expert system. Output were showed as user condition related depression and were completed with disease explanation and medical solution which showed in website with PHP programming of MySQL database. The conclution in this research were PHP programming and MySQL database evidently could be implemented in expert system engineering to diagnose depression. Certainty Factor method evidently could commit searching depression symtomp easily and rapidly. Online system could support user to get information about kind of disease, symptom, and medical solution for depression.
\end{abstract}

Keywords: Expert system, depression ,Certainty Factor, PHP MySQL.

Abstrak-Tujuan penelitian adalah merancang dan membangun rekayasa perangkat lunak sistem pakar berbasis web yang mampu mendiagnosa penyakit depresi pada manusia untuk mendapatkan solusi dan informasi dengan mudah dan cepat. Penelitian ini menggunakan metode analisa nilai kepastian (Certainty Factor) berdasarkan jawaban atas pertanyaan yang diberikan oleh user. Hasil yang ditampilkan berupa kondisi user terkait dengan depresi. Hasil juga dilengkapi dengan penjelesan penyakit dan solusi pengobatan yang ditampilkan dalam bentuk website menggunakan pemrograman PHP dengan database MySQL. Kesimpulan dalam penelitian ini adalah bahasa pemograman PHP dan MySQL terbukti mampu diimplementasikan dalam merekayasa sistem pakar untuk mendiagnosa penyakit depresi.Metode Certainty Factor terbukti mampu melakukan penelusuran /pelacakan gejala penyakit depresi dengan mudah dan cepat dengan memberikan nilai kepastian.Sistem online dapat membantu user mendapatkan informasi tentang jenis-jenis penyakit, gejala dan solusi pengobatan pada penyakit depresi.

Kata Kunci :Sistem pakar, depresi, Certainty Factor, PHP MySQL.

\section{PENDAHULUAN}

Kemajuan teknologi akhir-akhir ini telah banyak memberikan pengaruh tersendiri bagi perkembangan beberapa bidang seperti pertanian, ekonomi, pendidikan, pemerintahan, kesehatan, dan pengobatan. Pengaruhnya dapat dilihat dalam bentuk perangkat lunak. Salah satunya adalah kecerdasan buatan. Kecerdasan buatan atau artificial intelligent memiliki beberapa cabang ilmu yang lebih spesifik 
diantaranya adalah sistem pakar. Sistem pakar menurut (T.Sutojo. dkk, 2011) adalah suatu sistem yang dirancang untuk dapat menirukan keahlian seorang pakar dalam menjawab pertanyaan dan memecahkan suatu masalah. Sistem pakar akan memberikan pemecahan suatu masalah yang dapat dari dialog dengan pengguna. Dengan bantuan sistem pakar seorang yang bukan pakar atau ahli dapat menjawab pertanyaan, menyelesaikan masalah serta mengambil keputusan yang biasanya dilakukan oleh seorang pakar.

Menurut (Dadang Hawari, 2011) Depresi adalah gangguan alam perasaan (mood) yang ditandai dengan kemurungan dan kesedihan yang mendalam dan berkelanjutan sehingga hilangnya kegairahan hidup, tidak mengalami gangguan dalam menilai realitas (Reality Testing Ability/RTA, masih baik), kepribadian tetap utuh (tidak mengalami keretakan pribadi/splitting of personality) perilaku dapat terganggu tetapi dalam batas-batas normal. Deprsi merupakan masalah kesehatan jiwa yang utama dewasa ini, hal ini amat penting karena orang dengan depresi produktivitasnya akan menurun dan ini amat buruk akibatnya bagi suatu masyarakat, bangsa dan negara yang sedang membangun. Sistem pakar yang akan dibangun digunakan untuk mendiagnosa penyakit depresi pada manusia. Sistem ini dirancang menggunakan metode certainty factor. Teori certainty factor (CF) diusulkan oleh Shortliffe dan Buchanan pada tahun 1975 untuk mengakomodasi ketidakpastian pemikiran (inexact reasoning) seorang pakar. Seorang pakar, (misalnya dokter) sering kali menganalisis informasi yang ada dengan ungkapan seperti "mungkin", "kemu ngkinan besar", "hampir pasti". Untuk mengakomodasi hal ini kita menggunakan certainty factor (CF) guna menggambarkan tingkat keyakinan pakar terhadap masalah yang sedang dihadapi. (T.Sutojo. dkk, 2010:194) Certainty factor menyatakan kepercayaan dalam sebuah kejadian (atau fakta atau hipotesis) berdasarkan bukti atau penilaian pakar (Daniel, Gloria Virginia, 2010). Aplikasi sistem pakar ini dipergunakan untuk mendiagnosis penyakit depresi yang terjadi pada manusia yang diperoleh dari input, berupa gejala awal yang dirasakan penderita, gejala awal meliputi indikator yaitu : perasaan bersalah, gairah hidup menurun dan gaduh gelisah atau lemah tak berdaya.

\section{METODOLOGI PENELITIAN}

Adapun kerangka penelitian dalam metodologi penelitian ini dibuat agar langkah-langkah yang diambil penulis dalam perancangan ini tidak melenceng dari pokok pembahasan dan lebih mudah dipahami, maka urutan langkah-langkah akan dibuat secara sistematis sehingga dapat dijadikan pedoman yang jelas dan mudah untuk menyelesaikan permasalahan yang ada. Urutan langkah-langkah yang akan dibuat pada penelitian ini adalah Penelitian Pendahuluan; Pengumpulan Data; Analisa; Perancangan; Implementasi; Pengujian 


\section{HASIL DAN PEMBAHASAN}

\subsection{Data Jenis-Jenis Penyakit Depresi Pada Manusia}

Penyakit Depresi adalah gangguan alam perasaan (mood) yang ditandai dengan kemurungan dan kesedihan yang mendalam dan berkelanjutan sehingga hilangnya kegairahan hidup, tidak mengalami gangguan dalam menilai realitas (Reality Testing Ability/RTA, masih baik), kepribadian tetap utuh (tidak mengalami keretakan pribadi/splitting of personality) perilaku dapat terganggu tetapi dalam batas-batas normal. Masalah yang dibahas dalam penelitian ini adalah mengenai penyakit depresi pada manusia. Beberapa jenis penyakit depresi pada manusia dapat kita lihat pada Tabel berikut ini :

Tabel 1. Jenis-Jenis Penyakit Depresi Pada Manusia

\begin{tabular}{|l|l|l|}
\hline No & Kode & Nama-Nama Penyakit Depresi Pada Manusia \\
\hline 1 & P001 & Depresi Ringan \\
\hline 2 & P002 & Depresi Berat \\
\hline 3 & P003 & Hipomania \\
\hline 4 & P004 & Gangguan Bipolar \\
\hline
\end{tabular}

\subsection{Data Gejala-Gejala Penyakit Depresi Pada Manusia}

Dalam menganalisa data gejala dari beberapa jenis penyakit depresi pada manusia ini dilakukan perbandingan-perbandingan dari informasi yang diperoleh dari banyak buku dan seorang pakar (dokter yang ahli dalam bidangnya). Gejala adalah bentuk dari persepsi atau perilaku yang dapat dilihat dari penderita untuk menganalisa dan penetuan jenis dari penyakit depresi pada manusia itu sendiri. Gejala-gejala dari penyakit depresi pada manusia dapat kita lihat pada Tabel 2 berikut ini :

Tabel 2. Gejala-Gejala Penyakit Depresi Pada Manusia

\begin{tabular}{|l|l|l|}
\hline No & Kode Gejala & Gejala \\
\hline 1 & G001 & Suasana hati yang murung dan perasaan sedih berkepanjangan \\
\hline 2 & G002 & Kehilangan minat untuk melakukan sesuatu \\
\hline 3 & G003 & Kecemasan \\
\hline 4 & G004 & Kegelisahan \\
\hline 5 & G005 & Tidak mampu merasakan kebahagiaan \\
\hline 6 & G006 & Mudah lelah dan tak bergairah \\
\hline 7 & G007 & Gelisah dan kurang tidur \\
\hline 8 & G008 & Nafsu makan berkurang dan berat badan berkurang \\
\hline 9 & G009 & Sulit berkonsentrasi dan perhatian berkurang \\
\hline 10 & G010 & Menghindari komunikasi dari orang lain \\
\hline 11 & G011 & Selalu merasa bersalah dan kurang percaya diri \\
\hline 12 & G012 & Pesimis dan mudah putus asa \\
\hline 13 & G013 & Pernah mencoba untuk bunuh diri \\
\hline 14 & G014 & Beranggapan masa depan suram dan pesimistis \\
\hline 15 & G015 & Mengkhawatirkan hal-hal yang kecil \\
\hline 16 & G016 & Ketakutan yang diutarakan tanpa ditanya \\
\hline 17 & G017 & Mudah tersinggung dan mudah marah \\
\hline 18 & G018 & Berbicara cepat dan mudah omong kosong \\
\hline
\end{tabular}


Prosiding Seminar Nasional Riset Information

\begin{tabular}{|l|l|l|}
\hline No & Kode Gejala & Gejala \\
\hline 19 & G019 & Keraguan dalam mengambil keputusan \\
\hline 20 & G020 & Keluhan somatik \\
\hline 21 & G021 & Merasa dirinya paling hebat dan optimistik \\
\hline 22 & G022 & Merasa sangat mengenal orang lain \\
\hline 23 & G023 & Merasa dirinya sangat penting \\
\hline 24 & G024 & Sukar menahan diri dalam perilaku sehari-hari \\
\hline 25 & G025 & Merasa sangat bersemangat \\
\hline 26 & G026 & Menyusun rencana yang tidak masuk akal \\
\hline 27 & G027 & Membuat keputusan aneh dan cenderung membahayakan \\
\hline 28 & G028 & Boros dalam keuangan \\
\hline
\end{tabular}

Dalam sub_bab ini selain menguraikan data dari gejala penyakit depresi pada manusia, juga menguraikan nilai kepastian(CF) gejala penyakit depresi pada manusia. Nilai-nilai kepastian gejala penyakit depresi pada manusia dapat dilihat pada Tabel berikut ini:

Tabel 3. Nilai CF Pada Gejala Penyakit Depresi Pada Manusia

\begin{tabular}{|l|l|l|l|l|l|}
\hline No & Kode & Nilai & & \\
\hline & & P001 & P002 & P003 & P004 \\
\hline 1 & G001 & 1,0 & & & \\
\hline 2 & G002 & 0,8 & & & \\
\hline 3 & G003 & 0,6 & 0,8 & & \\
\hline 4 & G004 & & 0,6 & & \\
\hline 5 & G005 & & 0,6 & & \\
\hline 6 & G006 & 0,6 & & & \\
\hline 7 & G007 & & 0,6 & & 0,6 \\
\hline 8 & G008 & 0,4 & & & \\
\hline 9 & G009 & 0,4 & & & \\
\hline 10 & G010 & 0,4 & 0,4 & & \\
\hline 11 & G011 & & 0,6 & & \\
\hline 12 & G012 & & 0,6 & & 0,6 \\
\hline 13 & G013 & & 1,0 & & 0,8 \\
\hline 14 & G014 & & 0,6 & & \\
\hline 15 & G015 & 0,6 & & & \\
\hline 16 & G016 & & & & 0,6 \\
\hline 17 & G017 & 0,6 & & & 0,6 \\
\hline 18 & G018 & & & 0,8 & \\
\hline 19 & G019 & 0,6 & & & \\
\hline 20 & G020 & 0,6 & & & 0,6 \\
\hline 21 & G021 & & & 0,8 & \\
\hline 22 & G022 & & & 0,6 & 0,6 \\
\hline 23 & G023 & & & 1,0 & \\
\hline 24 & G024 & & & 0,8 & \\
\hline 25 & G025 & & & 0,6 & 0,6 \\
\hline 26 & G026 & & & 0,6 & \\
\hline 27 & G027 & & & & 1,0 \\
\hline 28 & G028 & & & 0,4 & \\
\hline
\end{tabular}


Certainty factor merupakan metode inferensi yang digunakan untuk menghadapi permasalahan dengan jawaban yang tidak memiliki kepastian penuh. Adapun ketentuan interprestasi CF dapat kita lihat pada Tabel berikut ini :

Tabel 4. Ketentuan Nilai Pada Metode Certainty Factor

\begin{tabular}{|l|l|l|}
\hline No & Uncertain Term & CF \\
\hline 1 & Pasti tidak & -0.1 \\
\hline 2 & Hampir pasti tidak & -0.8 \\
\hline 3 & Kemungkinan besar tidak & -0.6 \\
\hline 4 & Mungkin tidak & -0.4 \\
\hline 5 & Tidak tahu & -0.2 to 0.2 \\
\hline 6 & Mungkin & 0.4 \\
\hline 7 & Kemungkinan besar & 0.6 \\
\hline 8 & Hampir pasti & 0.8 \\
\hline 9 & Pasti & 1.0 \\
\hline
\end{tabular}

Dalam sub_bab ini selain menguraikan data dari gejala penyakit depresi pada manusia, juga menguraikan nilai-nilai kepastian (CF) pada gejala penyakit depresi pada manusia. Nilai-nilai kepastian pada gejala penyakit depresi pada manusia dapat kita lihat pada Tabel berikut ini:

Tabel 5. Nilai CF Pada Gejala Penyakit Depresi Pada Manusia

\begin{tabular}{|l|l|l|l|l|l|}
\hline No & Kode & \multicolumn{3}{|l|}{ Nilai } & \\
\hline & & P001 & P002 & P003 & P004 \\
\hline 1 & G001 & 1,0 & & & \\
\hline 2 & G002 & 0,8 & & & \\
\hline 3 & G003 & 0,6 & 0,8 & & \\
\hline 4 & G004 & & 0,6 & & \\
\hline 5 & G005 & & 0,6 & & \\
\hline 6 & G006 & 0,6 & & & \\
\hline 7 & G007 & & 0,6 & & 0,6 \\
\hline 8 & G008 & 0,4 & & & \\
\hline 9 & G009 & 0,4 & & & \\
\hline 10 & G010 & 0,4 & 0,4 & & \\
\hline 11 & G011 & & 0,6 & & \\
\hline 12 & G012 & & 0,6 & & 0,6 \\
\hline 13 & G013 & & 1,0 & & 0,8 \\
\hline 14 & G014 & & 0,6 & & \\
\hline 15 & G015 & 0,6 & & & \\
\hline 16 & G016 & & & & 0,6 \\
\hline 17 & G017 & 0,6 & & & 0,6 \\
\hline 18 & G018 & & & 0,8 & \\
\hline 19 & G019 & 0,6 & & & \\
\hline 20 & G020 & 0,6 & & & 0,6 \\
\hline 21 & G021 & & & 0,8 & \\
\hline 22 & G022 & & & 0,6 & 0,6 \\
\hline 23 & G023 & & & 1,0 & \\
\hline
\end{tabular}




\begin{tabular}{|c|c|c|c|c|c|}
\hline \multirow[t]{2}{*}{ No } & \multirow[t]{2}{*}{ Kode } & \multicolumn{4}{|l|}{ Nilai } \\
\hline & & P001 & P002 & P003 & P004 \\
\hline 24 & G024 & & & 0,8 & \\
\hline 25 & G025 & & & 0,6 & 0,6 \\
\hline 26 & G026 & & & 0,6 & \\
\hline 27 & G027 & & & & 1,0 \\
\hline 28 & G028 & & & 0,4 & \\
\hline
\end{tabular}

Certainty factor merupakan metode inferensi yang digunakan untuk menghadapi permasalahan dengan jawaban yang tidak memiliki kepastian penuh. Adapun ketentuan interprestasi CF dapat kita lihat pada Tabel berikut ini :

Tabel 6. Ketentuan Nilai Pada Metode Certainty Factor

\begin{tabular}{|l|l|l|}
\hline No & Uncertain Term & CF \\
\hline 1 & Pasti tidak & -0.1 \\
\hline 2 & Hampir pasti tidak & -0.8 \\
\hline 3 & Kemungkinan besar tidak & -0.6 \\
\hline 4 & Mungkin tidak & -0.4 \\
\hline 5 & Tidak tahu & -0.2 to 0.2 \\
\hline 6 & Mungkin & 0.4 \\
\hline 7 & Kemungkinan besar & 0.6 \\
\hline 8 & Hampir pasti & 0.8 \\
\hline 9 & Pasti & 1.0 \\
\hline
\end{tabular}

\section{KESIMPULAN}

Aplikasi sistem pakar melakukan penarikan kesimpulan menggunakan metode Certainty Factor berdasarkan jenis dan gejala dari penyakit depresi pada manusia yang dapat dipilih oleh user, user juga memberikan nilai prediksi tentang penyakit depresi pada manusia kemudian mesin akan melakukan penelusuran serta mengeluarkan hasil diagnosa dan kemungkinan solusi terbaik(1). Sistem yang dibangun dapat membantu masyarakat dalam mengenali jenis-jenis dan gangguan penyakit depresi pada manusia, dengan cara mencetak hasil diagnosa setelah melakukan konsultasi sehingga user dapat mendapatkan data hasil konsultasi berupa gejala dan solusi penanganan penyakit depresi pada manusia(2).

\section{DAFTAR PUSTAKA}

[1] A. S, Rosa dan M. Shalahuddin. 2014. Rekayasa Perangkat Lunak Terstruktur dan Berorientasi Objek, Jilid 2. Bandung: Informatika.

[2] Hawari, Dadang.2011.Manajemen stress, cemas dan depresi.Jakarta:Balai Penerbit FKUI.

[3] Hidayat, Heri. 2011. Cara Instan Menguasai Pemograman Web. Jakarta : AGOGOS PUBLISHING

[4] Kadir, Abdul. 2009. Membuat Aplikasi Web dengan PHP dan Database MySQL. Yogyakarta : ANDI.

[5] Kusrini. 2008. Aplikasi Sistem Pakar. Yogyakarta : ANDI.

[6] Nurhayati, Nunung, M. Taupan. 2012. Serba-serbi Kehamilan dan Perawatan Anak. Bandung : Yrama Widya. 